\title{
The Influence Of Investment Decisions And Financing Decisions On Firm Value With Profitability As Intervening Variables(Empirical Study On Companies Listed In Indonesian Sharia Stock Index)
}

\author{
Nurlela; Sulastri; Umar Hamdan AJ; Agustina Hanafi \\ Faculty of Economics, Sriwijaya University, Indonesia
}

http://dx.doi.org/10.18415/ijmmu.v6i2.758

\begin{abstract}
This study aims to analyze the effect of investment decisions and financing decisions on the firm value with profitability as an intervening variable. The variables in this study are current assets to total assets, fixed assets to total assets, debt to assets ratio, debt to equity ratio, return on assets, and free cash flow. The sample in this study were 85 companies listed in the Indonesian Islamic Stock Index (ISSI) in 2012-2016. Data collection techniques in this study are purposive sampling method. The analytical method used is path analysis. The results showed that investment decisions current assets to total assets did not affect profitability while fixed assets to total assets negatively affected profitability. Financing decisions do not affect profitability. Investment decisions have a negative effect on firm value. Financing decisions do not affect the value of the company. Profitability has a positive effect on company value. Profitability does not mediate te effect of investment decisions current assets to total assets on firm value while profitability mediates the effect of investment decisions fixed assets to total assets on firm value. Profitability does not mediate the effect of financing decisions on firm value.
\end{abstract}

Keywords: Investment Decision; Financing Decision; Profitability; Firm Value

\section{Introduction}

Firm value in several studies is measured by stock prices. Stock prices sometimes lack the true value of a company, because changes in stock prices are not only influenced by company performance but can also be influenced by external factors outside the company that are not related to the company. These external factors are national security conditions, political and social conditions, changes in government policies, changes in exchange rates, interest rates, etc. (Murtini, 2008). The proxy used to measure firm value in this study is free cash flow (FCF). According to Bringham and Houston (2010) free cash flow is cash flow that is truly available to be paid to investors (shareholders and debt owners) after the company has made all investments in fixed assets, new products, and working capital needed to maintain operations that ongoing. Furthermore, Bringham and Houston (2010) say one way for managers to make companies more valuable is to increase the company's free cash flow. According to Sartono (2012) free cash flow reflects a number of cash that is actually available for distribution to investors. 
Investment decisions are very important, because through investment decisions companies can realize company goals as stated by Fama (1978). Investment decisions concerning decisions about determining the allocation of funds into investment forms (Sartono, 2012). Investment decisions are differentiated into short-term investment decisions and long-term investment decisions. Short-term investment decisions are measured by Current Assets to Total Assets (CATA) as in Hasnawati (2005) and Efni et al (2014), while long-term investment decisions are measured by Fixed Assets to Total Assets (FATA) as in Hasnawati and Sawir (2015) research. Determination of investment decisions in fixed assets and current assets is very dependent on the type of company and the products produced. Manufacturing companies invest more in fixed assets while trading companies or service companies invest more in current assets. The company will choose investments that generate the highest return with risk that can be managed so that the company's wealth can be increased.

Financing decisions is also affect the firm value. Financing decision in this study is measured by Debt to Assets Ratio (DAR). According to Kasmir (2013) the DAR ratio compares the total debt to total assets. Financing decisions were also measured by Debt to Equity Ratio (DER). This ratio compares the company's debt with the company's own capital.

One measure of a company's financial performance is profitability. According to Kasmir (2013) profitability is a ratio to assess a company's ability to make a profit. The ability to generate profits can be used to project the company's ability to generate cash in the future because one source of free cash flow (FCF) is profit (Herliana et al, 2016). As much higher ROA then FCF is also high. In this study profitability is used as an intervening variable between investment decisions and financing decisions on firm value. Profitability is measured by ROA.

The object of this research are companies listed in the Indonesian Syariah Stock Index (ISSI), the reason the authors chose ISSI because the majority of the population of Indonesia are muslim and Indonesia is one of the biggest muslim countries in the world. The large number of Muslim investors requires a stock investment that is in accordance with Islamic Sharia. Islamic stocks based on DSN Fatwa No. 59 of 2007 is a certificate that shows proof of ownership of a company issued by an issuer whose business activities and management methods do not conflict with sharia principles.

Based on previous studies that provide inconsistent results that give rise to the existence of research gaps arouse the interest of researchers to further examine the influence of investment decisions and financing decisions on the firm value with profitability as an intervening variable. This study entitled "The Influence of Investment Decisions and Financing Decisions on Firm Value with Profitability as Intervening Variables (Empirical Study of Companies Listed in the Indonesian Islamic Stock Index)".

\section{Literature Study And Hypothesis}

\section{MM theory}

Proposition I of MM theory says that if there is no tax, the value of the company is not dependent on debt. Proposition II of MM theory says that the cost of debt is smaller than the cost of equity. Increased use of debt will increase risk and result in increased capital costs. The conclusion of proposition II argument is that the use of debt cannot increase the value of the company because the increase in the cost of equity cannot cover the benefits of the smaller debt costs.

In situations where there is tax, MM theory says that debt can increase the value of the company, companies that use debt will bear interest costs, the interest costs will be a deduction from tax payments as a result of which operating profits will be greater.

\section{Pecking Order Theory}

Pecking order theory suggests that companies prioritize the use of internal funds, namely with retained earnings. If external funding is needed, the company will first issue debt and issue equity as a last resort. 


\section{Trade-Off Theory}

According to the trade-off theory, the company will exchange the tax benefits from using debt funding with problems caused by the potential for bankruptcy. Common stock and preferred stock will be more expensive than debt because of the interest expense paid and tax deduction.

\section{Investment decision}

Investment decisions are decisions regarding the use of funds to buy company assets. Investment decisions in this study were measured by Current Assets to Total Assets (CATA) as in Hasnawati (2005). The CATA ratio can be calculated using a formula (Syamsuddin, 2013):

\section{CATA $=($ Current Assets $) /($ Total Asset $)$}

The Current Assets to Total Asset (CATA) ratio compares current assets to total assets. According to Syamsudin (2013) This ratio shows how many parts of total assets are embedded in current accounts.

Investment decisions in this study were also measured using Fixed Assets to Total Assets (FATA) as in Hasnawati and Sawir (2015). FATA can be calculated using the formula:

FATA $=($ Fixed Assets $) /($ Total Asset $)$

The Fixed Assets to Total Asset (FATA) ratio compares fixed assets to total assets.

\section{Financing Decision}

Financing decisions are financial decisions about where funds are to buy company assets (Atmaja, 2008). Financing decision in this study is measured by Debt to Assets Ratio (DAR). The formula for Debt to Assets Ratio (DAR) is as follows (Kasmir, 2013):

$\mathrm{DAR}=($ Total Debt $) /($ Total Assets $)$

According to Kasmir (2013) the DAR ratio compares the total debt with total assets.

Financing decisions in this study were also measured using Debt to Equity Ratio (DER) as in the study of Christi (2013) and Khan et al (2016). The Debt to Equity Ratio (DER) formula is as follows:

$$
\text { DER }=(\text { Total debt }) /(\text { Total equity })
$$

This ratio compares the total debt with total equity or own capital owned by the company.

\section{Profitability}

Profitability is management effectiveness shown by profits generated from sales or company investments (Weston \& Copeland, 2010). This study uses the ROA ratio as an indicator of profitability. This ratio compares the net profit after tax with the total assets. The formula for Return on Assets (ROA) is as follows (Kasmir, 2013: 202): ROA = (Profit after tax) / (Total Assets)

\section{Firm Value}

In this study the value of the company is proxied by free cash flow (FCF). According to Sartono (2012) free cash flow is available cash flow after deducting company expenses in investing in fixed assets, and working capital needed to maintain its business continuity, where the cash flow will later be paid to investors. Mathematically free cash flow (FCF) is calculated as in (Ross et al 2009):

Free Cash Flow = Operating cash flow - Capital expenditure - Net Working Capital 
Information :

$\mathrm{FCF}=$ Free cash flow

Ako = Operating cash flow

$\mathrm{PM}=$ Capital Expenditures

$\mathrm{NWC}=$ Net working capital

\section{Sharia Shares}

Sharia products must comply with sharia principles. Based on Bapepam and LK Regulation Number IXA.13 concerning the Issuance of Sharia Securities, a share can be said to be sharia if the business and management are in accordance with the principles of the Shariah. Source of Sharia law based on the fatwa of the national sharia council (DSN) Number 40 / DSN-MUI / X / 2003 concerning the Capital Market and General Guidelines for the Implementation of Sharia Principles in the Capital Market based on: the Qur'an, the Hadith of the Prophet Muhammad, and rules jurisprudence.

\section{Hypothesis}

H1: Investment decision (CATA) has a positive effect on profitability (ROA)

H2: Investment decision (FATA) has a negative effect on profitability (ROA)

H3 : Financing decisions (DAR) have a positive effect on profitability (ROA)

H4: Financing decisions (DER) have a positive effect on profitability (ROA)

H5: Investment decisions (CATA) have a negative effect on firm value (FCF)

H6: Investment decisions (FATA) have a negative effect on firm value (FCF)

H7: $\quad$ Financing decisions (DAR) have a positive effect on firm value (FCF)

H8: $\quad$ Financing decisions (DER) have a positive effect on firm value (FCF)

H9: $\quad$ Profitability has a positive effect on firm value (FCF)

H10: Profitability mediates the effect of investment decisions (CATA) on firm value (FCF).

H11: Profitability mediates the effect of investment decisions (FATA) on firm value (FCF).

H12: Profitability mediates the effect of financing decisions (DAR) on firm value (FCF).

H13: Profitability mediates the effect of finaning decisions (DER) on firm value (FCF.

\section{Research Methods}

The population in this study were all companies incorporated in the ISSI for the years 2012-2016. The sample was chosen based on the purposive sampling method so that 85 companies were selected with 425 panel data. This study uses path analysis.

Concept defination of endogeneous and eksogeneous are explained as follow :

1. The firm value in this study is measured by free cash flow.

$\mathrm{FCF}=$ Ako $-\mathrm{PM}-\mathrm{NWC}$

Information :

Ako $=$ Operating cash flow

$\mathrm{FCF}=$ Free cash flow 
$\mathrm{PM}=$ Capital Expenditures

$\mathrm{NWC}=$ Net working capital $/$ net working capital

2. Investment decision in this study are measured by CATA and FATA.

CATA $=($ Current Asset $) /($ Total Asset $)$

FATA $=($ Fixed Assets $) /($ Total Assets $)$

3. Financing Decision in this study were measured by DAR and DER.

$\mathrm{DAR}=($ Total Debt $) /($ Total Assets $)$

DER $=($ Total Debt $) /$ Equity

4. Profitability

ROA $=($ Profit after tax $) /($ Total Assets $)$

\section{Research result}

This study uses path analysis. The results of path analysis after normality test, SEM assumption test and multicollinearity and modification of indices. The result show there were 315 panel data. The path as seen in Figure 1

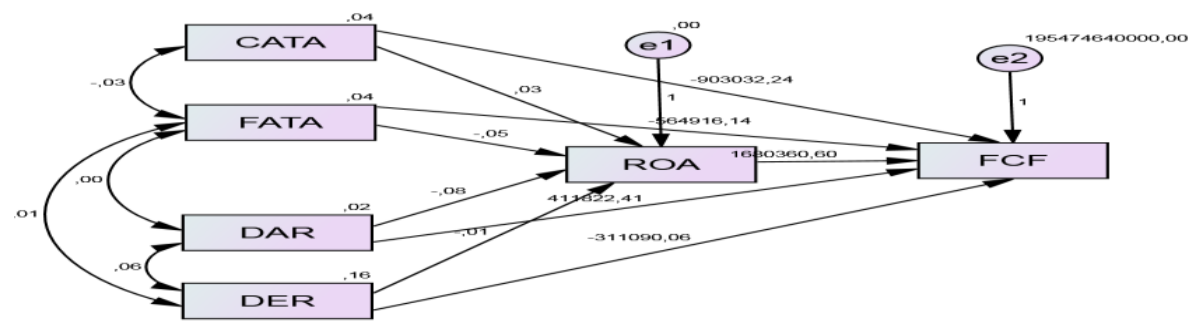

$$
\begin{aligned}
& \text { Chi-Square }=4,780 \\
& \text { Probability }=, 092 \\
& \text { RMSEA }=, 067 \\
& \text { GFI }=, 995 \\
& \text { AGFI }=, 947 \\
& \text { CFI }=, 998 \\
& \text { TLI }=, 992
\end{aligned}
$$

\section{Figure 1 Path analysis}

The results of the test for significance of exogenous variables on endogenous variables are presented in Table 1.

Examination of direct effect coefficients and indirect effects of exogenous variables on endogenous variables are presented in tables 2,3,4 and 5.

The results of the direct influence test, indirect effects and the effect of total exogenous variables on endogenous variables are presented in tables 6 and 7. 
Table 1 Significance test

\begin{tabular}{llllll}
\hline & & & Significance & Parameter & Remarks \\
\hline ROA & $<---$ & FATA &, 003 &,- 208 & Negative Significant \\
ROA & $<---$ & DAR &, 341 &,- 211 & Not Significant \\
ROA & $<---$ & DER &, 725 &,- 077 & Not Significant \\
ROA & $<---$ & CATA &, 096 &, 116 & Not Significant \\
FCF & $<---$ & DAR &, 583 &, 123 & Not Significant \\
FCF & $<---$ & FATA &, 001 &,- 236 & Negative Significant \\
FCF & $<---$ & DER & 235 &,- 265 & Not Significant \\
FCF & $<---$ & CATA & $* * *$ &,- 393 & Negative Significant \\
FCF & $<---$ & ROA &, 001 &, 183 & Positive Significant \\
\hline
\end{tabular}

Source : Research data Processed

Table 2 Examination Coefficients of Direct and Indirect Influence of Investment Decision (CATA) on Firm Value

\begin{tabular}{lllll}
\hline & Parameter & Signifikansi & Keterangan & Kesimpulan \\
\hline CATA $\rightarrow$ FCF & $-0,393$ & $* * *$ & Significant & \\
CATA $\rightarrow$ ROA & 0,116 & 0,096 & Not Significant & Not Mediation \\
ROA $\rightarrow$ FCF & 0,183 & 0,001 & Significant & \\
\hline
\end{tabular}

Source : Research data Processed

Table 3 Examination Coefficients of Direct and Indirect Influence of Investment Decision (FATA) on Firm Value

\begin{tabular}{lllll}
\hline & Parameter & Signifikansi & Keterangan & Kesimpulan \\
\hline FATA $\rightarrow$ FCF & $-0,236$ & 0,001 & Significant & \\
FATA $\rightarrow$ ROA & $-0,208$ & 0,003 & Significant & Mediation \\
ROA $\rightarrow$ FCF & 0,183 & 0,001 & Significant & \\
\hline
\end{tabular}

Source : Research data Processed

Table 4 Examination Coefficients of Direct and Indirect Influence of Financing Decision (DAR) on Firm Value

\begin{tabular}{lllll}
\hline & Parameter & Signifikansi & Keterangan & Kesimpulan \\
\hline DAR $\rightarrow$ FCF & 0,123 & 0,583 & Not Significant & \\
DAR $\rightarrow$ ROA & $-0,211$ & 0,341 & Not Significant & Not Mediation \\
ROA $\rightarrow$ FCF & 0,183 & 0,001 & Significant & \\
\hline
\end{tabular}


Table 5 Examination Coefficients of Direct and Indirect Influence of Financing Decision (DER) on Firm Value

\begin{tabular}{lllll}
\hline & Parameter & Signifikansi & Keterangan & Kesimpulan \\
\hline $\mathrm{DER} \rightarrow$ FCF & $-0,265$ & 0,235 & Not Significant & \\
$\mathrm{DER} \rightarrow$ ROA & $-0,077$ & 0,725 & Not Significant & \multirow{2}{*}{ Not Mediation } \\
ROA $\rightarrow$ FCF & 0,183 & 0,001 & Significant & \\
\hline
\end{tabular}

Source : Research data Processed

Table 6 Direct and indirect effect of investment decisions (CATA and FATA) on firm value (FCF)

\begin{tabular}{llll}
\hline & Direct Effect & Indirect Effect & Total \\
\hline CATA ke FCF & $-\mathbf{- 3 9 3}$ & $\mathbf{, 0 2 1}$ & $-\mathbf{3 7 1}$ \\
FATA ke FCF & $\mathbf{- , 2 3 6}$ & $\mathbf{, 0 3 8}$ & $-\mathbf{- 2 7 4}$ \\
\hline \multicolumn{4}{c}{ Source : Research data Processed }
\end{tabular}

Table \& Direct and indirect effect of financing decisions (DAr and DER) on firm value (FCF)

\begin{tabular}{lccc}
\hline & Direct Effect & Indirect Effect & Total \\
\hline DAR ke FCF & $\mathbf{, 1 2 3}$ & $\mathbf{, 0 3 9}$ & $\mathbf{, 0 8 5}$ \\
DER ke FCF & $\mathbf{- , 2 6 5}$ & $\mathbf{- , 0 1 4}$ &,- 279 \\
\hline
\end{tabular}

Source : Research data Processed

\section{Effect of Investment Decisions on Profitability}

The results showed that CATA had no effect on ROA. The results of this study indicate that the high and low ROA is not influenced by the high and low CATA but is influenced by whether or not the utilization of the current assets is effective or not. The results of this study are not in line with Rahmiyatun's research (2016) which found that CATA had a significant effect on profitability. Saleh et al (2015) research also found that the asset structure measured by CATA had an effect on profitability.

The test results show that FATA has a negative effect on ROA because the sample companies that have high amounts of fixed assets must bear large depreciation costs. investments that are too heavy on fixed assets are not profitable due to annual depreciation expenses (Jumingan, 2009).

\section{Effect of financing decision on Profitability}

The test results show that DAR does not affect ROA, which means that the high and low DAR does not affect the high and low ROA. DAR has no effect on ROA, this is because additional debt is not used for company operations that generate profits but is used for investment in assets that do not generate profits, so the addition of debt does not affect the increase in profits.

The test results show that DER does not affect ROA, which means that the high and low DER does not affect the high and low ROA, because the use of debt in the sample company is relatively small so that it does not affect the increase in profit.

\section{Effect of Investment Decisions on Firm Value}

The test results show that CATA has a negative effect on FCF. it means that the height of CATA has an effect on the high and low of FCF, because the direction of the relationship is negative means that 
the greater the CATA the smaller the FCF. FCF is obtained from operating cash flows minus capital expenditure and changes in net working capital. Addition of current assets causes net working capital to increase, causing FCF to decline.

The test results show that FATA has an effect on FCF, which means that the height of FATA has an effect on the height of FCF with a negative relationship which means that the higher the FATA, the lower the FCF this is because the addition of fixed assets will cause capital expenditure to be high, causing the FCF to be low.

\section{Effect of Financing Decisions on Firm Value}

The test results show that DAR has no effect on FCF because the sample company has a relatively small DAR so that the interest expense borne by the company is also small, besides that FCF is more influenced by capital expenditure on fixed assets and the company's current assets.

The test results show that DER has no effect on FCF The sample company has a relatively small DER so that the interest expense borne by the company is also small, besides that FCF is more influenced by capital expenditure on fixed assets and the company's current assets..

\section{Effect of Profitability on Firm Value}

The test results show that ROA has a positive effect on FCF. The company's ability to generate profits can be used to project the company's ability to generate cash in the future because one source of free cash flow (FCF) is profit (Herliana et al, 2016).

\section{Effect of Investment Decisions on Firm Value Through Profitability as Intervening}

The results of path analysis to measure the ROA variable as a mediation of the effect of investment decisions (CATA) on firm value based on the results of the examination (Table 3 ) found that ROA is not an intervening variable. The size of CATA does not have an effect on ROA, because ROA is more determined by the effectiveness of the company in utilizing its current assets. Increased profitability cannot strengthen CATA's influence on company value.

The results of path analysis to measure the ROA variable as a mediation of the effect of investment decisions (FATA) on firm value (FCF) indicate that ROA is an intervening variable. Investment decisions (FATA) affect the value of the company directly and indirectly. Based on the results of the examination (Table 4), it shows that partial mediation occurs because FATA's direct influence on firm value is significantly negative and FATA's indirect influence on ROA is significantly negative and the effect of ROA on firm value is significantly positive. ROA can strengthen FATA's relationship with company value. This can be interpreted that when ROA increases, the relationship between FATA and company value will be stronger. Companies that have high FATA will bear a high depreciation burden so that ROA decreases, and will result in free cash flow as a proxy for the company's value to also decline.

\section{Effects of Financing Decision on Firm Value Through Profitability as Intervening}

The results of path analysis to measure the ROA variable as a mediating effect of investment decisions (DAR) on firm value (FCF) found that ROA is not an intervening variable. Based on the results of the type of mediation examination (Table 5) it was found that ROA does not mediate the effect of funding decisions as measured by DAR on firm value. The size of DAR does not have an effect on profitability. Increased profitability cannot strengthen the influence of DAR on firm value. This result does not support the trade-off theory which states that increasing debt can provide tax protection benefits so that the higher the debt, the operating profit of the company that flows to investors increases. 
Path analysis results to measure ROA variables as mediating the effect of financing decisions (DER) on firm value (FCF) based on the results of the examination (Table 6) found that profitability is not an intervening variable, profitability does not mediate the relationship between DER and firm value. The size of the DER has no effect on profitability. Increased profitability cannot strengthen the influence of DER on firm value. This result does not support the trade-off theory which states that increasing debt can provide tax protection benefits so that the higher the debt, the operating profit of the company that flows to investors increases.

\section{Conclusion}

1. Investment decisions measured by CATA have no effect on profitability.

2. Investment decisions measured by FATA have a negative effect on profitability.

3. Financing decisions as measured by DAR do not affect on profitability.

4. Financing decisions as measured by DER have no effect on profitability.

5. Investment decisions as measured by CATA have a negative effect on firm value.

6. Investment decisions that are measured by FATA have a negative effect on firm value.

7. Financing decisions as measured by DAR do not affect on the firm value.

8. Financing decisions as measured by DER do not affect on the firm value.

9. Profitability has a positive significant effect on the firm value.

10. Profitability cannot mediate the effect of investment decisions as measured by CATA on firm value.

11. Profitability mediates the effect of investment decisions as measured by FATA on firm value. In this case partial mediation occurs.

12. Profitability does not mediate the effect of financing decisions as measured by DAR on firm value.

13. Profitability does not mediate the effect of financing decisions as measured by

DER on firm value.

\section{References}

Atmaja, lukas setia. (2008). Teori dan Praktek Manajemen Keuangan. Edisi 1. Yogyakarta : Andi Bringham, Eugene F dan Joel F. Houston. 2010. Dasar-Dasar Manajemen Keuangan. . Jakarta : Salemba Empat.

Chisti, Khalid Ashraf., Ali, Khusheed., Sangmi, Mouh-i-Din. (2014). Impact of Capital Structure On Profitability of Listed Companies (Evidence From India). The USV Annals of Economic and Public Administration. Vol. 13 Issue 1 (17).

Efni, Yulia., Siregar, Ruth \& Fathoni, A.F. (2014). Pengaruh Keputusan Investasi dan Kebijakan Dividen yang Dimediasi oleh Variabel Risiko terhadap Nilai Perusahaan Studi pada Perusahaan Manufaktur Sektor Aneka Industri yang Terdaftar di BEI periode 2008-2012. JOM Fekon. Vol.1. No. 2, $2014: 1-15$.

Fatwa Dewan Syariah Nasional No. 59/DSN-MUI/V/2007. Dewan Syariah Nasional MUI. 2007, Jakarta 
Hasnawati, Sri. (2005). Dampak Set Peluang Investasi Terhadap Nilai Perusahaan Publik di Bursa Efek Jakarta. JAAI. Vol. 9 No. PP : 117 - 126.

Hasnawati, Sri \& Sawir, Agnes. (2015). Keputusan Keuangan, ukuran Perusahaan, Struktur Kepemilikan dan Nilai perusahaan Publik di Indonesia. Jurnal Manjaemen dan Kewirausahaan. Vol. 17 No. 1, $2015: 65-75$.

Herliana, D. A., Budiarjo, D. \& Komalasari, P.T. (2016). Pengaruh Free Cash Flow terhadap Kinerja Perusahaan Melalui Agency Cost Sebagai Variabel antara pada Perusahaan Manufaktur yang Terdaftar di BEI. Jurnal Ekonomi \& Bisnis Airlangga Vol. 26 No.3. 2016.

Jumingan. (2009). Analisis Laporan Keuangan. Jakarta : Bumi Aksara.

Kasmir. (2013). Analisis Laporan Keuangan, Edisi 1, Cetakan Ketujuh, Jakarta : Raja Grafindo Persada.

Khan, Akmal., Shaikh, Maria.,Shah, A.B.,Zahid, Imtiaz.,Shaikh, F.M. (2017). Impact of Financing Decisions on Firm's Performance : An Empirical Study of Pakistani Listed Firm's in KSE. International Journal of Management and Information Technology. Vol. 12, No.1.

Murtini, Umi. (2008). Pengaruh Kebijkan Manajemen Keuangan terhadap Nilai Perusahaan. Jurnal Akuntansi dan Keuangan. Vol. 4 No. 1, 2008 : 32-47.

Rahmiyatun, Fitri.,Nainggolan, Kaman. (2016). Pengaruh Struktur Aktiva, Perputaran Modal dan Pendanaan terhadap Profitabilitas Perusahaan Farmasi. Ecodemica, Vol. 4. No. 2. 2016 : 156-166.

Ross, Stephen A.,Westerfield, Randolph. W., Jordan, Bradford. D. (2009). Pengantar Keuangan Perusahaan Corporate Finance Fundamentals. Jakarta : Salemba Empat.

Saleh, Hatta.,Priawan, Sunu \& Ratnawati, Tri. (2015). Pengaruh Struktur Aktiva, Struktur Modal dan Risiko Pasar terhadap Pertumbuhan, Profitabilitas, dan Nilai Perusahaan (Studi pada Perusahaan Manufaktur di BEI). International Journal of Bisnis dan Manajemen Invention. Vol. 4 No. 12. $2015: 45-53$.

Sartono, Agus. (2012). Manajemen Keuangan Teori dan Aplikasi. Yogyakarta : BPFE Yogyakarta.

Syamsuddin, Lukman. (2013). Manajemen Keuangan Perusahaan : Konsep Aplikasi dalam Perencanaan, Pengawasan, dan Pengambilan Keputusan. Jakarta : PT Raja Grafindo Persada.

www.ojk.go.id/id/kanal/syariah/pages/Pasar-Modal-Syariah.aspx

www.idx.co.id/idx-syariah/indeks-saham-syariah/

\section{Copyrights}

Copyright for this article is retained by the author(s), with first publication rights granted to the journal. This is an open-access article distributed under the terms and conditions of the Creative Commons Attribution license (http://creativecommons.org/licenses/by/4.0/). 